\title{
Production and stability studies of the bioemulsifier obtained from a new strain of Candida glabrata UCP 1002
}

\author{
Leonie Asfora Sarubbo \\ Núcleo de Pesquisas em Ciências Ambientais (NPCIAMB) \\ Departamento de Química \\ Universidade Católica de Pernambuco \\ Rua Nunes Machado, n.42, B1 J, Boa Vista \\ CEP: $50050-590$ \\ Recife-PE, Brazil \\ Tel: 558121194017 \\ Fax: 558121194043 \\ E-mail: leonie@unicap.br \\ Juliana Moura de Luna \\ Núcleo de Pesquisas em Ciências Ambientais (NPCIAMB) \\ Mestrado em Ciências Biológicas \\ Centro de Ciências Biológicas \\ Universidade Federal de Pernambuco \\ Av, Prof. Moraes Rêgo, s/n, Cidade Universitária \\ CEP: 50900-000 \\ Recife-PE, Brazil \\ Galba Maria de Campos-Takaki* \\ Núcleo de Pesquisas em Ciências Ambientais (NPCIAMB) \\ Departamento de Química \\ Universidade Católica de Pernambuco \\ Rua Nunes Machado, n.42, B1 J, Boa Vista \\ CEP: $50050-590$ \\ Recife-PE, Brazil \\ Tel: 558121194017 \\ Fax: 558121194043 \\ E-mail: takaki@unicap.br
}

Website: http://www.unicap.br

Financial support: The work was financed by Agência Financiadora de Estudos e Projetos (FINEP), Conselho Nacional de Desenvolvimento Científico e Tecnológico (CNPq) and Universidade Católica de Pernambuco (UNICAP), Pernambuco, Brazil.

Keywords: biosurfactant, Candida, emulsifier, fermentation, glucose, vegetal oil.

Abbreviations: CMC: critical micellar concentration

CYM: Yeast Mold Broth

YMA: Yeast Mold Agar

Evaluation of both tenso-active and emulsifying activities indicated that a biosurfactant was produced by the newly isolated and promising strain Candida glabrata isolated from mangrove sediments. The extracellular water-soluble emulsifying agent was isolated and identified as a heteropolymer. The maximum of bioemulsifier production was observed when the strain was grown on soluble and insoluble substrates cotton seed oil plus glucose, reaching values of $10.0 \mathrm{~g} / \mathrm{l}$ after $144 \mathrm{hrs}$ at $200 \mathrm{rpm}$. The cell-free culture broth containing the examined agent lowered the surface tension of the medium to $31 \mathrm{mN} / \mathrm{m}$. Stable and compact emulsions with emulsifying activity of $75 \%$ of cotton seed oil were detected. The emulsification capacity remained practically unaltered within a wide pH (2-12), temperature $\left(4-80^{\circ} \mathrm{C}\right)$ ranges and under $\mathrm{NaCl}$ concentrations up to $10 \%$.

*Corresponding author 


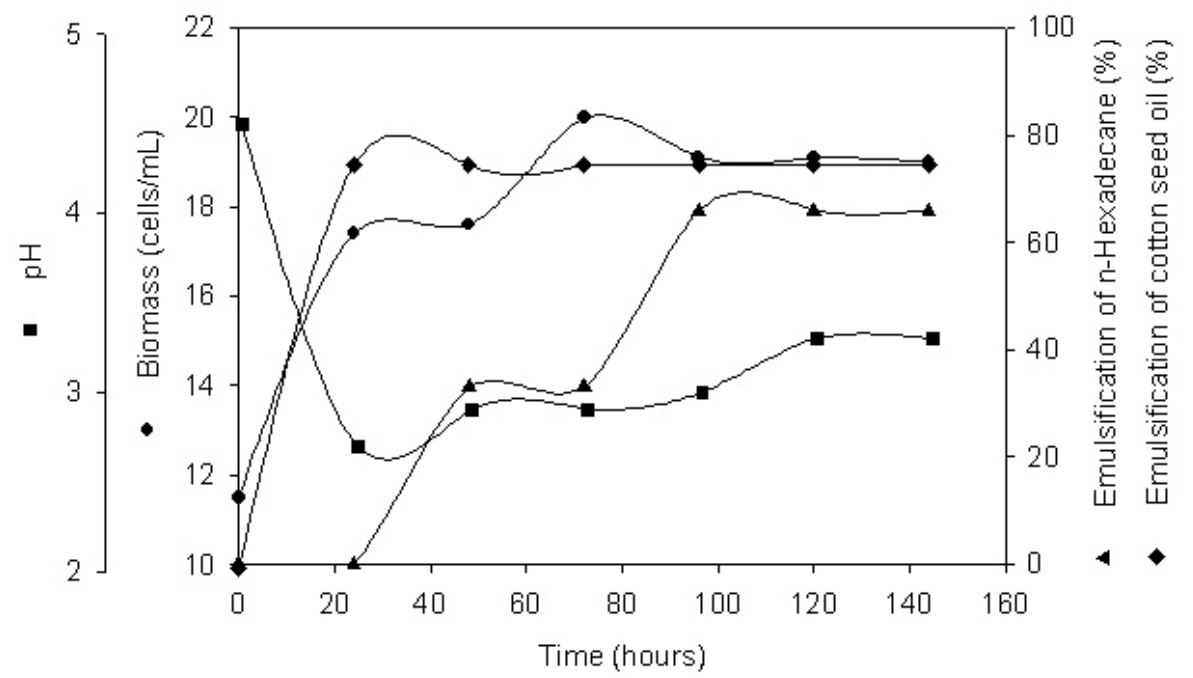

Figure 1. Time courses of growth, culture $\mathrm{pH}$ and emulsifications of $\mathrm{n}$-hexadecane and cotton seed oil by Candida glabrata grown on mineral medium supplemented with $7.5 \%$ cotton seed oil plus $5.0 \%$ glucose.

Surfactants and emulsifiers are indispensable components of daily life. They are widely used in the pharmaceutical, cosmetic, petroleum and food industries (Makkar and Cameotra, 1998; Lang, 2002). The surfactant industry now exceeds US\$ 9 billion per year (Desai and Banat, 1997). Most of these compounds are of petroleum origin, which are not easily biodegradable and their manufacturing processes and by-products can be environmentally hazardous. Increased environmental awareness and strict legislation has made environmental compatibility of surfactants an important factor in their applications for various uses (Maier and Soberon-Chavez, 2000). Several different microbial products that exhibit surface-active properties have been identified in the past. These so called biosurfactants are produced by certain bacteria and by a number of yeasts and filamentous fungi. They include lowmolecular-weight glycolipids, lipopeptides and highmolecular-weight lipid-containing polymers such as lipoproteins, lipopolyssacharide-protein complexes and polysaccharide-protein-fatty acid complexes (Ron and Rosenberg, 2001). Because biosurfactants are readly biodegradable and can be produced in large amounts by microorganisms and thus are not dependent on petroleumderived products, they might well be able to replace, in some instances, the traditional synthetic surfactants (Banat et al. 2000).

The success of biosurfactant production depends on the development of cheaper processes and the use of low cost raw materials, which account for $10-30 \%$ of the overall cost. Most oils and fats produced in the world are used in the food industry, which generates great quantities of wastes, tallow, lard, marine oils and free fatty acids from the extraction of seed oils (Makkar and Cameotra, 1998; Makkar and Cameotra, 2002). The literature shows that a wide range of carbon sources, including agricultural renewable resources, like sugars and oils, are suitable carbon sources for production of ecologically safe biosurfactants with good properties. (Gallert and Winter, 2002). Optimal yields of bioemulsifier are usually obtained when carbohydrate and vegetable oil are used as substrate (Zhou and Kosaric, 1995).

Among yeasts, Candida species have been widely employed for insoluble substrates fermentation and have been reported to produce surface active agents (Sarubbo et al. 1999; Sarubbo et al. 2001). The objective of this work is to investigate the production of a biosurfactant by Candida glabrata isolated from mangrove sediments and to show the capacity of the emulsifying agent in stabilizing water-in-oil emulsions.

\section{MATERIALS AND METHODS}

\section{Organism}

Candida glabrata UCP 1002 was isolated from mangrove sediment collected in the City of Rio Formoso, Pernambuco State, Brazil by Gomes et al. (2000). The isolation and identification of strain are according to O'Donnell (1979). The organism was kindly supplied from the Culture Collection of Nucleous of Resource in Environmental Sciences, Catholic University of Pernambuco, Recife, PE, Brazil. The culture was maintained at $5^{\circ} \mathrm{C}$ on Yeast Mold Agar (YMA) slants containing (w/v): yeast extract $(0.3 \%)$, malt extract $(0.3 \%)$, tryptone $(0.5 \%)$, D-glucose $(1 \%)$ and agar $(5 \%)$. Transfers were made to fresh agar slants each month to maintain viability.

\section{Reagents}

n-Hexadecane was obtained from Sigma Chemical Co. (St. Louis, MO); food grade cotton seed oil was kindly supplied 


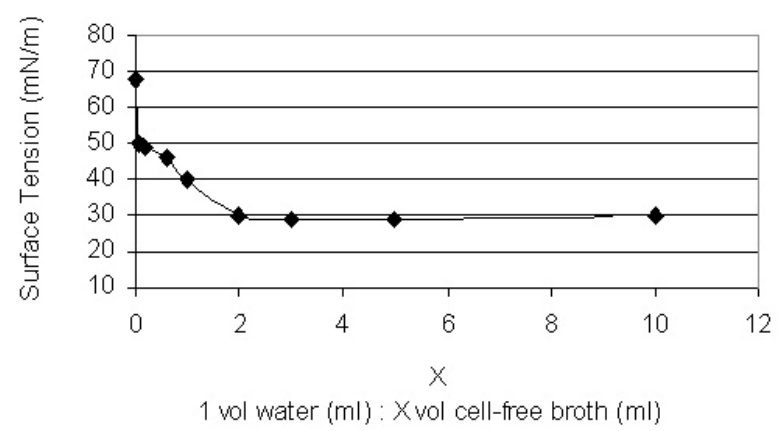

Figure 2. Surface tension reduction of distilled water by the cell-free broth of Candida glabrata grown on mineral medium supplemented with $7.5 \%$ cotton seed oil plus $5.0 \%$ glucose.

from Bunge Alimentos S.A. (SC, Brasil). Other chemicals used were analytical grade.

\section{Media and cultivation conditions}

Cultures were grown on a mineral medium containing $0.1 \%$ $\mathrm{NH}_{4} \mathrm{NO}_{3}, 0.02 \% \mathrm{KH}_{2} \mathrm{PO}_{4}, 0.02 \% \mathrm{MgSO}_{4} .7 \mathrm{H}_{2} \mathrm{O}, 0.3 \%$ yeast extract and $7.5 \%$ cotton seed oil plus $5.0 \%$ glucose as substrates. The final $\mathrm{pH}$ of the medium was 5.7.

The Candida glabrata was grown in solid medium at $27^{\circ} \mathrm{C}$ for 48-72 hrs; then, a loopful of the cream coloured culture was transferred to Erlenmeyer flasks of $250 \mathrm{ml}$ containing $50 \mathrm{ml}$ of the liquid medium, Yeast Mold Broth (CYM) and incubated for one day at $27^{\circ} \mathrm{C}$ on an orbital shaker $(200$ $\mathrm{rpm})$. The CYM culture contained $10^{4}$ cells $/ \mathrm{ml}$ and was used to initiate growth in mineral medium using a $10 \%$ $\mathrm{vol} / \mathrm{vol}$ inoculum. The production of the emulsifier was carried out in Erlenmeyer's flasks of $500 \mathrm{ml}$ containing 100 $\mathrm{ml}$ of the production medium and shaking at $200 \mathrm{rpm}$ for $144 \mathrm{hrs}$ at $27^{\circ} \mathrm{C}$. The $\mathrm{pH}$ of the media was not adjusted during cultivation. Growth of the culture was monitored by counts on Neubauer Camera and plate YMA. The fermentation's was monitored by aseptically removing of samples until the end of the experiment. All analyses were performed in triplicate and did not vary more than 5\%.

\section{Emulsification activity}

Emulsification activity was measured using the method described by Cooper and Goldenberg (1987) whereby $6 \mathrm{ml}$ of n-hexadecane or cotton seed oil was added to $4 \mathrm{ml}$ of the culture broth free of cells in a graduated screwcap test tube and vortexed at $3000 \mathrm{rpm}$ for $2 \mathrm{~min}$. The emulsion stability was determined after $24 \mathrm{hrs}$, and the emulsification index was calculated by dividing the measured height of the emulsion layer by the mixture's total height and multiplying by 100 .

\section{Efficiency studies}

The efficiency of the biosurfactant as an emulsifying agent was measured on the cell-free broth. Variations between volumes of the oil phase (n-hexadecane or cotton seed oil) and aqueous phase were prepared for water in oil emulsions.

\section{Stability studies}

Stability studies were done using the cell-free broth obtained centrifuging the cultures at $10000 \mathrm{xg}$ for $15 \mathrm{~min}$. $4 \mathrm{ml}$ of the culture broth free of cells were heated at $80^{\circ} \mathrm{C}$, and cooled to room temperature, after which the emulsification activity was measured. The emulsification capacity of culture broth free of cells was also determined after exposure at lower temperature $\left(0-4^{\circ} \mathrm{C}\right)$. To study the $\mathrm{pH}$ stability of the cell-free broth, the $\mathrm{pH}$ of the cell-free broth was adjusted to different $\mathrm{pH}$ values (2 to 12 ) and the emulsification activity was measured. The culture liquid $\mathrm{pH}$ was adjusted with $1 \mathrm{M} \mathrm{NaOH}$. The effect of $\mathrm{NaCl}$ concentrations ( 2 to $10 \%$ ) on the emulsification capacity of the culture broth free of cells was also determined.

\section{Surface activities}

Surface tension and critical micellar concentration (CMC) were determined on cell-free broth obtained by centrifuging the cultures at $10000 \mathrm{x} \mathrm{g}$ for $15 \mathrm{~min}$ with a Tensiometer model Sigma 70 (KSV Instruments LTD - Finland) using the Du Nouy ring method at room temperature. The CMC was determined by measuring the surface tensions of dilutions of cell-free broth in distilled water up to a constant value of surface tension. Measurements of surface tension from distilled water and from the mineral medium were used as controls.

\section{Isolation of biosurfactant}

The 144-h culture was refrigerated for 24 hrs to solidify the remaining oil and to effect yeast settling. The culture was filtered through Whatman no. 1 filter paper and centrifuged at $10000 \mathrm{x} \mathrm{g}$ for $15 \mathrm{~min}$. The cell-free broth was concentrated $(500 \mathrm{ml})$ by freeze drying and extracted three times with chloroform (1:1, by vol.) in a separatory funnel at $28^{\circ} \mathrm{C}$.

\section{Analytical methods}

Protein concentration in the isolated bioemulsifier was determined by the Lowry method (Lowry et al. 1951) using Bovine serum albumin as a standard. Carbohydrates were determined by the phenol-sulphuric acid method, using Dglucose as a standard (Hanson and Phillips, 1981). The lipid composition of the crude bioemulsifier was determined according to Manocha et al. (1980).

\section{RESULTS AND DISCUSSION}

\section{Growth kinetics and extracellular bioemulsifier} production 


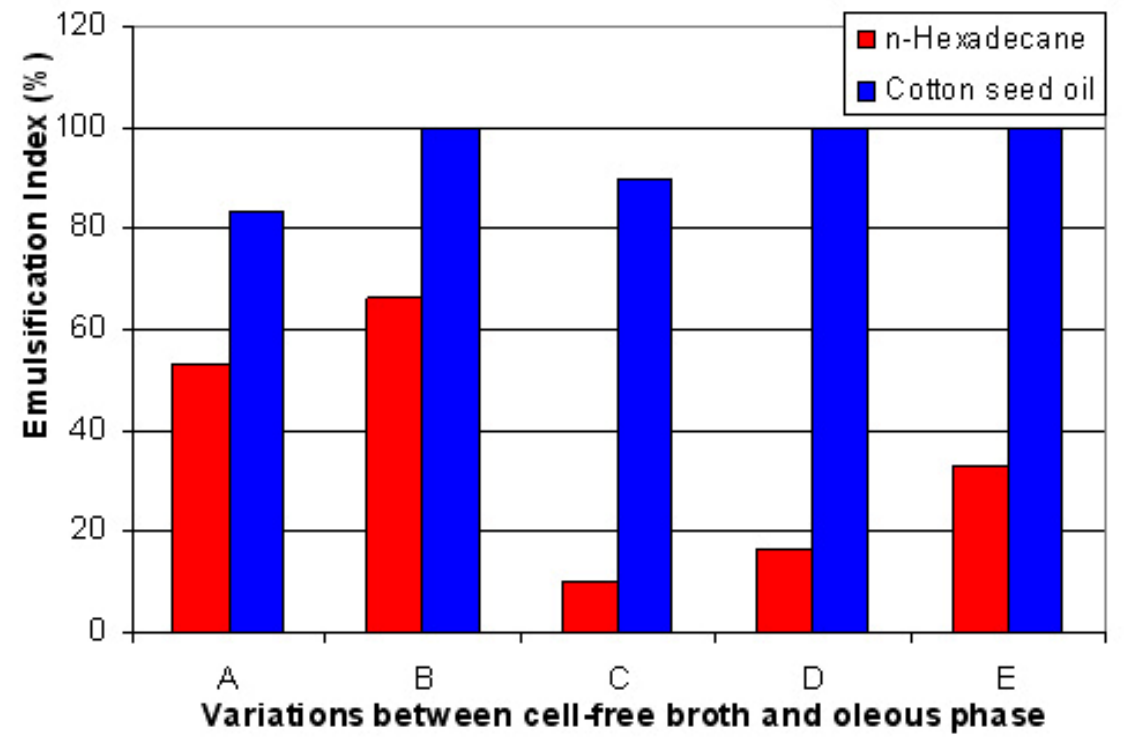

Figure 3. Efficiency of emulsifying activity of cell-free broth of Candida glabrata grown on mineral medium supplemented with $\mathbf{7 . 5 \%}$ cotton seed oil plus $\mathbf{5 . 0 \%}$ glucose as a function of volumesvariation between the cell-free broth (aqueous phase) and the substrate (oil phase), respectively. $(A=3.0 \mathrm{ml}$ and $2.5 \mathrm{ml} ; B=2.5 \mathrm{ml}$ and $3.0 \mathrm{ml} ; C=2.0 \mathrm{ml}$ and $3.5 \mathrm{ml} ; \mathrm{D}=1.5 \mathrm{ml}$ and $4.0 \mathrm{ml} ; \mathrm{E}=$ $1.0 \mathrm{ml}$ and $4.5 \mathrm{ml})$.

Figure 1 shows the biomass concentration, $\mathrm{pH}$ and emulsification index of Candida glabrata cultivation in mineral medium containing $7.5 \%$ of cotton seed oil plus $5 \%$ of glucose. Maximum biomass concentration was achieved after $72 \mathrm{hrs}$. After $48 \mathrm{hrs}$ of growth, a diauxic behaviour was observed, probably due to the consumption of other substrate used in the fermentation. During the exponential growth phase, culture medium $\mathrm{pH}$ gradually decreased from 5.7 to 2.6, after which it remained around 3.0. The profile of emulsification activity production was observed in three independently run fermentations. Emulsification of cotton seed oil increased with increasing biomass formation, reaching its optimum nearly at about $24 \mathrm{hrs}$, and after 48 hrs of growth it showed with constant values around $75 \%$ until the end of cultivation. Conversely, the emulsification of n-hexadecane started after the microorganism entered the stationary growth phase, with maximum activity of $67 \%$ after $96 \mathrm{hrs}$ of cultivation.

\section{Bioemulsifier properties}

For the measurements of surface tension of distilled water after different dilutions of the cell-free broth after $144 \mathrm{hrs}$ of cultivation, it was found that the emulsifier agent obtained from glucose plus cotton seed oil could lower the surface tension of water (air-water interface) from 68 $\mathrm{mN} / \mathrm{m}$ to $31 \mathrm{mN} / \mathrm{m}$ (CMC), which shows that it is a good surfactant (Figure 2). This result is similar to others surfactants produced by yeast from carbohydrate and vegetal oil as substrates (Davila et al. 1992; Zhou and Kosaric, 1995; Garcia-Ochoa and Casas, 1999).
The efficiency of the bioemulsifier containing cell-free broth is shown in Figure 3. The results showed that the biosurfactant form Candida glabrata was efficient in emulsificating the cotton seed oil once no significant variation in the emulsification index was observed for this substrate, however, for n-hexadecane emulsification, the reduction of cell-free broth volume decreased the emulsification capacity.

The effect of added $\mathrm{NaCl}$ concentrations on n-hexadecane and cotton seed oil emulsification capacity of the cell-free broth is summarized in Figure 4. A reduction of approximately $20 \%$ of emulsification activity was observed with the addition of up to $10 \%(\mathrm{w} / \mathrm{v})$ sodium chloride for both substrates, showing a relative tolerance over these salt concentrations. Once the salinity decreases the viscosity, it is possible that the increase of $\mathrm{NaCl}$ concentration had influenced the quality of the emulsion, thus reducing the emulsification capacity. Reductions in emulsification activity were also reported for other surfactants of microorganisms as Candida lipolytica grown in nhexadecane (Cirigliano and Carman, 1984) and a mixed culture cultivated in molasses (Ghurye et al. 1994).

The effect of thermal treatment on the emulsifier activity of Candada glabrata culture showed that no appreciable changes in emulsification capacity occurred, if the cell-free broth was heated, once only $10 \%$ of activity was lost at $80^{\circ} \mathrm{C}$. The lost of emulsifier activity could be explained by the denaturation of proteinaceous compounds of the bioemulsifier during heating. There was no significant change at lower temperature $\left(4^{\circ} \mathrm{C}\right)$. Liposan from Candida lipolytica found to be relatively stable between 30 and 


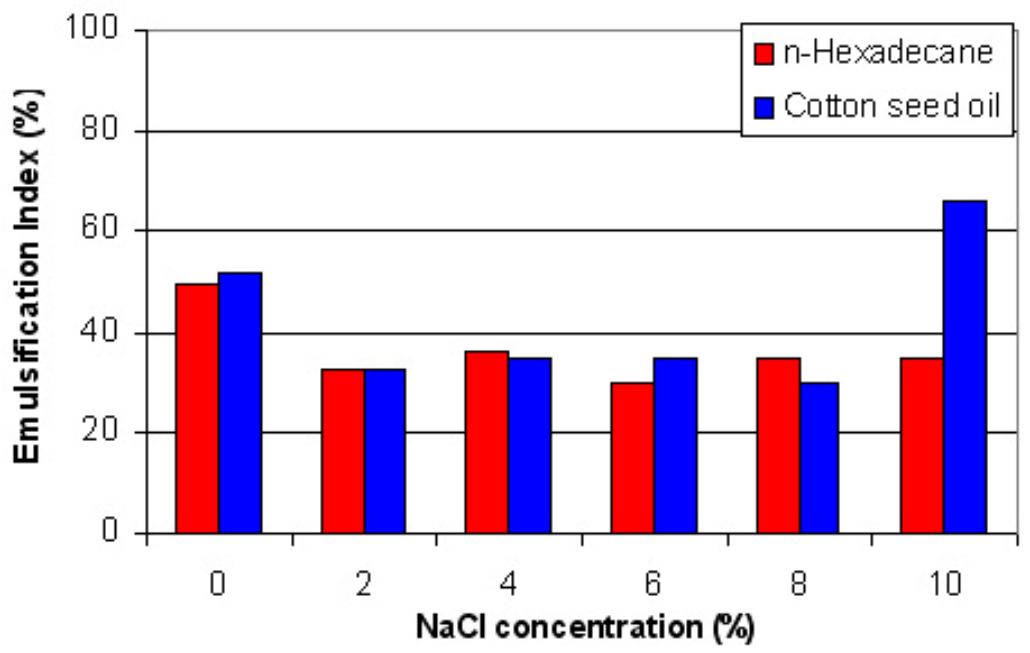

Figure 4. Effect of different sodium chloride concentrations on the emulsifying activity of cell-free broth of Candida glabrata grown on mineral medium supplemented with $7.5 \%$ cotton seed oil plus $5.0 \%$ glucose.

$90^{\circ} \mathrm{C}$, but lost $60 \%$ of its activity after boiling for $1 \mathrm{hr}$ (Cirigliano and Carman, 1984).

The $\mathrm{pH}$ of the cell-free broth was varied from 2 to 12 to test the effect of $\mathrm{pH}$ on emulsification capacity. No appreciable effect on activity was observed along the $\mathrm{pH}$ range, although it was observed an increase at $\mathrm{pH} 12$, especially for cotton seed oil emulsification. Extremes of $\mathrm{pH}$ could possibly transform less surface-active species into more active emulsifiers by increased ionization. The activity of the biosurfactant produced by Bacillus subtillis was also $\mathrm{pH}$ stable (Makkar and Cameotra, 1998), while the effectiviness of liposan as emulsifier was limited to the acid to neutral $\mathrm{pH}$ (Cirigliano and Carman, 1984).

\section{Bioemulsifier isolation}

The examined agent was isolated from the culture filtrate of Candida glabrata. The precipitate collected in the aqueous phase recovered $100 \%$ of the emulsification activity of $n$ hexadecane that was present in the culture filtrate, while the emulsification activity of the cotton seed oil increased $25 \%$. The average yield of precipitate in the aqueous phase was approximately $10.0 \mathrm{~g} / \mathrm{l}$. Bioemulsifier production by yeast Candida utilis varied from 0.26 to $0.93 \mathrm{~g} / 1$ and depended on process conditions (Shepherd et al. 1995), while the extracellular emulsifying agent from Curvularia lunata yielded 2.6 g/l (Paraszkiewicz et al. 2002). The emulsification activity of both the isolated biosurfactant and the cell-free remained stable for a reasonable period (more than 4 weeks) under low temperature and upon sterilization.

\section{Preliminary bioemulsifier}

Bioshyntesis of biosurfactants from a variety of bacteria and yeasts has been reported (Davila et al. 1992; Zhou and Kosaric, 1995; Daniel et al. 1999; Lang and Wullbrandt, 1999), most commonly involving rhamno-lipids, trehalose and sophorose-lipids. These usually contain various hydroxy fatty acids and carbohydrates and are characterized by unique surfactant properties (Ron and Rosenberg, 2001). Preliminary analysis of the bioemulsifier produced by the new strain Candida glabrata indicated that it was a heteropolymer, which consisted of $45 \%$ protein, $20 \%$ lipid and $10 \%$ carbohydrate. Liposan, an extracellular emulsifier synthesized by Candida lipolytica was composed of $93 \%$ carbohydrate and $7 \%$ protein (Cirigliano and Carman, 1984). Other polymeric emulsifiers containing proteins, carbohydrates and lipids were also produced by Candida lipolytica when grown in babassu vegetal oil (Sarubbo et al. 1999) or glucose (Sarubbo et al. 2001) as the sole carbon sources.

\section{CONCLUDING REMARKS}

The results obtained in this work show that this new strain of Candida glabrata represents a valuable source of new compounds with surface-active properties, with potential of application in different industries. Work is in progress to improve the production process of these compounds by using industrial wastes as substrates.

\section{REFERENCES}

BANAT, I.M.; MAKKAR, R.S. and CAMEOTRA, S.S. Potential commercial applications of microbial surfactants. Applied Microbiology and Biotechnology, May 2000, vol. 53, no. 5, p. 495-508.

CIRIGLIANO, M.C. and CARMAN, G.M. Isolation of a bioemulsifier from Candida lipolytica. Applied and 
Environmental Microbiology, October 1984, vol. 48, no. 4, p. 747-750.

COOPER, David G. and GOLDENBERG, Beena G. Surface-active agents from two Bacillus species. Applied and Environmental Microbiology, February 1987, vol. 53, no. 2, p. 224-229.

DANIEL, H-J.; OTTO, R.T.; BINDER, M.; REUS, M. and SYLDATK, C. Production of sophorolipids from whey: development of a two-stage process with Cryptococcus curvatus ATCC 20509 and Candida bombicola ATCC 22214 using deproteinized whey concentrates as substrates. Applied Microbiology and Biotechnology, January 1999, vol. 51, no. 1, p. 40-45.

DAVILA, Anne-Marie; MARCHAL, Rémy and VANDECASTEELE, Jean-Paul. Kinetics and balance of fermentation free from product inhibition: sophorose lipid production by Candida bombicola. Applied Microbiology and Biotechnology, October 1992, vol. 38, no. 1, p. 6-11.

DESAI, J.D. and BANAT, I.M. Microbial production of surfactants and their commercial potential. Microbiology and Molecular Biology Reviews, March 1997, vol. 61, no. 1, p. 47-64.

GALLERT, C. and WINTER, J. Solid and liquid residues as raw materials for biotechnology. Naturwissenschaften, November 2002, vol. 89, no. 11, p. 483-496.

GARCIA-OCHOA, F. and CASAS, J.A. Unstructured kinetic model for sophorolipid production by Candida bombicola. Enzyme and Microbial Technology, October 1999, vol. 25, no. 7, p. 613-621.

GHURYE, G.L.; VIPULANANDAN, C. and WILSON, R.C. A practical approach to biosurfactant production using nonaseptic fermentation of mixed cultures. Biotechnology and Bioengineering, August 1994, vol. 44, no. 5, p. 661666.

GOMES, P.F.; NASCIMENTO, A.E.; OKADA, K.; MESSIAS, A.S.; SHARIA, A.E.N. and CAMPOSTAKAKI, G.M. Aspectos da qualidade de ecossistemas do Município do Rio Formoso. In: International Conference: Sustainable use of estuaries and mangroves: challenges and prospects. Recife-Pe, Brasil, Abstracts, 2000. p. 82.

HANSON, R.S. and PHILLIPS, J.A. Chemical Composition. In: GHERHARDT, P. ed. Manual of Methods for General Bacteriology, American Society for Microbiology, Washington, DC, 1981, p. 328-364.

LANG, S. and WULLBRANDT, D. Rhamnose lipidsbiosynthesis, microbial production and application potential. Applied Microbiology and Biotechnology, January 1999, vol. 51, no. 1, p. 22-32.
LANG, Siegmund. Biological amphiphiles (microbial biosurfactants). Current Opinion in Colloid and Interface Science, March 2002, vol. 7, no. 1-2, p. 12-20.

LOWRY, Oliver H.; ROSEBROUGH, Nira J.; FARR, A. Lewis and RANDALL, Rose J. Protein measurement with the folin phenol reagent. Journal of Biological Chemistry, November 1951, vol. 193, no. 1, p. 265-275.

MAIER, R.M. and SOBERON-CHAVEZ, G. Pseudomonas aeruginosa rhamnolipids: biosynthesis and potential applications. Applied Microbiology and Biotechnology, November 2000, vol. 54, no. 5, p. 625-633.

MAKKAR, R.S. and CAMEOTRA, S.S. Production of biosurfactant at mesophilic and thermophilic conditions by a strain of Bacillus subtillis. Journal of Industrial Microbiology and Biotechnology, January 1998, vol. 20, no. 1, p. $48-52$.

MAKKAR, R.S. and CAMEOTRA, S.S. An update on the use of unconventional substrates for biosurfactant production and their new applications. Applied Microbiology and Biotechnology, March 2002, vol. 58, no. 4, p. 428-434.

MANOCHA, M.S.; SAN-BLAS, G. and CENTENO, S. Lipid composition of Paracoccidioides brasilienses: possible correlation with virulence of different strains. Journal of General Microbiology, March 1980, vol. 117, no. 1, p. 147-154.

O'DONNELL, K.L. Zygomycetes in culture. Palfrey Contributions in Botany. Athens, Department of Botany, University of Georgia, 1979. 257 p. ISBN 0935460012.

PARASZKIEWICZ, Katarzyna; KANWAL, Anita and DLUGONSKI, Jerzy. Emulsifier production by steroid transforming filamentous fungus Curvularia lunata. Growth and product characterization. Journal of Biotechnology, January 2002, vol. 92, no. 3, p. 287-294.

RON, Eliora Z. and ROSENBERG, Eugene. Natural roles of biosurfactants. Environmental Microbiology, April 2001, vol. 3 , no. 4, p. 229-236.

SARUBBO, L.A.; PORTO, A.L.F. and CAMPOSTAKAKI, G.M. The use of babassu oil as substrate to produce bioemulsifiers by Candida lipolytica. Canadian Journal of Microbiology, May 1999, vol.45, no. 5, p. 423426.

SARUBBO, Leonie A.; MARÇAL, Maria Do Carmo; NEVES, Maria Luisa C.; SILVA, Maria Da Paz C.; PORTO, Ana Lúcia F. and CAMPOS-TAKAKI, Galba Maria. Bioemulsifier production in batch culture using glucose as carbon source by Candida lipolytica. Applied Biochemistry and Biotechnology, July 2001, vol. 95, no. 1, p. 59-68. 
SHEPHERD, Rachel; ROCKEY, John; SHUTHERLAND, Ian W. and ROLLER, Sibel. Novel bioemulsifiers from microorganisms for use in foods. Journal of Biotechnology, June 1995, vol. 40, no. 3, p. 207-217.

ZHOU, Q.-H. and KOSARIC, N. Utilization of Canola Oil and lactose to produce biosurfactant with Candida bombicola. Journal of the American Oil and Chemists' Society, 1995, vol. 72, p. 67-71. 